\title{
Association of Job Stress and Hypertension among Nurses in Imo State, Nigeria
}

\author{
Chinedu-Eleonu, P.O. ${ }^{1}$, Obasi, C.C. ${ }^{2}$, Nsonwu, M.C. ${ }^{3}$, Akaogu. A.O. ${ }^{3}$, \\ Chukwu, R.O. ${ }^{2}$ \\ ${ }^{1}$ Department of Public Health, Imo State University Owerri, Nigeria \\ ${ }^{2}$ Department of Public Health, Federal University of Technology, Owerri, Imo State, Nigeria \\ ${ }^{3}$ Department of Optometry, Imo State University Owerri, Nigeria \\ Corresponding Author: Chinedu-Eleonu, P.O.
}

\section{ABSTRACT}

Hypertension is one of the major public health problems and it is prevalent all over the world. Raised blood pressure (BP) is a major risk factor for chronic heart disease, stroke and coronary heart disease. This study was a descriptive and correlation study carried out to investigate the association of job stress and hypertension among nurses in Imo state, Nigeria. A wellstructured questionnaire was used to interview the subjects and obtain data for the study. All subjects used for this study gave an informed consent to be part of the study. Data analysis was performed using SPSS Statistics version 23. Bivariate (unadjusted) discriminant analysis method was used to assess the correlation of hypertension with job stress. Results showed that significant correlation was found between hypertension and job stress (Wilks's Lambda $=0.965, \quad \mathrm{~F}=13.85, \quad \mathrm{p}<0.0001), \quad \mathrm{a}$ significant proportion (34.3\%) of the hypertensive nurses stated that they feel stressful working on night compared with $19.0 \%$ who are non-hypertensive. But the corresponding mean score (2.6) remained the same for both groups. Up to $21.8 \%$ of the nonhypertensive nurses compared with $32.1 \%$ of the hypertensive nurses reported that most of the times they deprive themselves from sleeping just to perform work task. The mean score showed variations for two groups with higher score for the non-hypertensive among those that find it stressful to engage in a non-nursing task while on duty (non-hypertensive 2.6, hypertensive 2.3). The score was rather higher in the hypertensive (3.0) than the nonhypertensive (2.5) among those who responded
\end{abstract}

that the task they handle make them feel fatigued. In conclusion, there was a correlation between job stress and hypertension. It was recommended that stress intervention programmes be introduced to encourage nurses to manage stress in the workplace.

Keywords: Hypertension, High Blood Pressure, Job stress, Nurses, Cardiovascular disease

\section{INTRODUCTION}

Hypertension is a core public health problem with high prevalence all over the world. ${ }^{[1]}$ Up to 7.5 million deaths or $12.8 \%$ of the entire yearly deaths that occurred globally were as a result of high blood pressure. ${ }^{[2]}$ It is predicted to increase to 1.56 billion adults with hypertension in 2025. ${ }^{[3]}$ Raised blood pressure (BP) is a major risk factor for chronic heart disease, stroke and coronary heart disease. Raised BP has shown positive correlation with the risk of other diseases such as stroke and coronary heart disease. ${ }^{[3]}$ Its complications include heart failure, peripheral vascular disease, renal impairment, retinal hemorrhage and visual impairment. [4] Hypertension (HTN) or high blood pressure (HBP) is defined as abnormally high arterial blood pressure. According to Akpa et al. ${ }^{[5]}$, blood pressure is regarded as normal if the level is $120 / 80 \mathrm{mmHg}$ or less and low if the level is lower than $90 \mathrm{mmHg}$ systolic or $60 \mathrm{mmHg}$ diastolic. The blood pressure between $120 / 80 \mathrm{mmHg}$ and $130 / 89 \mathrm{mmHg}$ is 
regarded as pre-hypertension, where as a blood pressure of $140 / 90 \mathrm{mmHg}$ and above is considered to be hypertension. The disease hypertension is also known as a silent killer because it does not present with apparent symptoms from the beginning, hence, the individual suffering from it may not know. Since some people may not be aware of the existence of excessive blood pressure, it is only through measurement that detection can be done. Although majority of patients with hypertension remain asymptomatic, some people with HTN may report headaches, light headache, vertigo, altered vision or fainting episode. ${ }^{[6]}$

In Nigeria, it is recorded that the prevalence of hypertension may form a substantial proportion of the total burden in Africa. This is because the country's population is estimated to be over 170 million. Africans as observed by WHO ${ }^{[7]}$ has the highest occurrence of hypertension and it is frequently associated with the elderly. It is estimated that over $46 \%$ of adult Africans suffer from the disease, making some people to associate it with African race. ${ }^{[1]}$ According to the World Health Statistics Report ${ }^{[8]}$, the prevalence of hypertension among adults aged 18 years and older was $22.2 \%$ in 2014 and Africa was identified to be the region with the highest prevalence of $29.6 \%$. First of all, the elevated blood pressure significantly accelerates the progression of arterial failure within various body organs (heart, brain, kidney, etc.), promoting the development of hypertension. The toll of hypertension as a chronic disease in the population and the negative impact on the already stressed medical system is of serious concern. Shifting the resources from preventable communicable diseases to the management of chronic diseases is a serious task both to the government and families. [9] The emergence of hypertension as a noncommunicable disease and a public health problem in the developing countries is strongly related to aging, urbanization, socio-economic changes favoring sedentary habits, alcohol consumption, salt intake, marital condition, smoking, job stress among others. Jiang et al. ${ }^{[10]}$ posited that the prevalence of hypertension varies across regions and countries. Hypertension with its complication is about $25 \%$ of all medical emergence cases of admission and $66 \%$ of all hospital admission in Nigeria. ${ }^{[1]}$ Shift duties can lead to destruction of biological homeostasis thereby leading to hypertension to the shift workers including nurses. ${ }^{[12]}$

Job stress is defined as "A set of psychosocial factors experienced by workers due to work conditions, generated as composite experiences at different levels within an organization. ${ }^{[13],}$ Among environmental factors, job stress is an important determinant of hypertension and is well-studied in developed countries. ${ }^{[14]} \mathrm{It}$ is very important to understand the role of stress at the organizational level and understand how this relates to hypertension in Low- and Middle-Income Countries (LMIC) such as India. It is estimated that in LMIC, a smaller proportion of a healthy workforce will have to bear responsibility for a large and increasingly aging population. Hence public health researchers in these countries need to recognize the window of opportunity to address factors that can reduce cardiovascular disease risk at workplaces. ${ }^{[15]}$ Job stress has become a serious health issue, not just in terms of an individual's mental and physical well-being, but also for employers and governments who have begun to access the financial consequences of work stress. ${ }^{[16]}$ Some factors affecting job stress include poor support from supervisors and co-workers, lack of role clarity, low level of control etc. Stress at work places that may predispose nurses to high blood pressure are long working hours, shift duties, lifting of heavy patients, and little or no off duties after long night shift among others. According to Rosengren et al. ${ }^{[17]}$, the association between the incidence of hypertension and all the above-mentioned work strain affect women (including nurses) mostly. A study by Radi et al. ${ }^{[18]}$ revealed that working conditions and cardiovascular health among women 
workers have recently increased more than that of men. Job strain and long work hours have been identified as important risk factors for hypertension. ${ }^{[19]}$ This study was carried out to investigate the association of job stress and hypertension among nurses in Imo state, Nigeria.

\section{MATERIALS AND METHODS}

This study was a descriptive and correlation study carried out in Imo State, Nigeria. A well-structured questionnaire was used to interview the subjects and obtain data for the study. All subjects used for this study gave an informed consent to be part of the study. Data analysis was performed using SPSS Statistics version 23. Bivariate (unadjusted) discriminant analysis method was used to assess the correlation of hypertension with job stress.

\section{RESULTS}

Table 1: Summary of descriptive statistics showing frequency and percentage of Hypertension Status among nurses studied

\begin{tabular}{|c|c|c|}
\hline Hypertension Status & $\mathbf{n}$ & $\mathbf{\%}$ \\
\hline Not Hypertensive & 248 & 63.9 \\
\hline Hypertensive & 140 & 36.1 \\
\hline Total & $\mathbf{3 8 8}$ & $\mathbf{1 0 0}$ \\
\hline Hypertensive Group & & \\
\hline Stage 1 hypertension & 127 & 90.7 \\
\hline Stage 2 hypertension & 13 & 9.3 \\
\hline Total & $\mathbf{1 4 0}$ & $\mathbf{1 0 0 . 0}$ \\
\hline
\end{tabular}

Table 2: Distribution for Job Stress and Hypertension Status among Nurses in Imo State

\begin{tabular}{|c|c|c|c|c|c|c|c|c|c|c|}
\hline \multirow[t]{2}{*}{ Item } & \multicolumn{5}{|c|}{ Non-Hypertensive } & \multicolumn{5}{|c|}{ Hypertensive } \\
\hline & $\begin{array}{c}\text { MT } \\
(\mathbf{p t}=4) \\
\text { n }(\%)\end{array}$ & $\begin{array}{c}\text { OT } \\
(p t=3) \\
n(\%)\end{array}$ & $\begin{array}{c}\text { ST } \\
(\mathrm{pt}=2) \\
\mathrm{n}(\%)\end{array}$ & $\begin{array}{c}\mathrm{R} \\
(\mathrm{pt}=1) \\
\mathbf{n}(\%)\end{array}$ & $\begin{array}{l}\text { Mean } \\
\text { (S.D) }\end{array}$ & $\begin{array}{c}\text { MT } \\
(\mathrm{pt}=4) \\
\mathrm{n}(\%)\end{array}$ & $\begin{array}{c}\text { OT } \\
(\mathrm{pt}=3) \\
\mathrm{n}(\%)\end{array}$ & $\begin{array}{c}\mathrm{ST} \\
(\mathrm{pt}=2) \\
\mathbf{n}(\%)\end{array}$ & $\begin{array}{c}\mathbf{R} \\
(\mathrm{pt}=1) \\
\mathbf{n}(\%)\end{array}$ & $\begin{array}{l}\text { Mean } \\
\text { (S.D) }\end{array}$ \\
\hline $\begin{array}{l}\text { My job demand makes me feel } \\
\text { tensed }\end{array}$ & $\begin{array}{c}56 \\
(22.6)\end{array}$ & $\begin{array}{c}132 \\
(53.2)\end{array}$ & $\begin{array}{c}34 \\
(13.7)\end{array}$ & $\begin{array}{c}26 \\
(10.5)\end{array}$ & $\begin{array}{c}2.9 \\
(0.68)\end{array}$ & $\begin{array}{c}31 \\
(22.1)\end{array}$ & $\begin{array}{c}70 \\
(50.0)\end{array}$ & $\begin{array}{c}17 \\
(12.1)\end{array}$ & $\begin{array}{c}22 \\
(15.7)\end{array}$ & $\begin{array}{c}2.8 \\
(0.63)\end{array}$ \\
\hline $\begin{array}{l}\text { I stressful working on the night } \\
\text { shift }\end{array}$ & $\begin{array}{c}47 \\
(19.0) \\
\end{array}$ & $\begin{array}{c}99 \\
(39.9)\end{array}$ & $\begin{array}{c}46 \\
(18.5) \\
\end{array}$ & $\begin{array}{c}56 \\
(22.6) \\
\end{array}$ & $\begin{array}{c}2.6 \\
(0.44) \\
\end{array}$ & $\begin{array}{c}48 \\
(34.3) \\
\end{array}$ & $\begin{array}{c}24 \\
(17.1) \\
\end{array}$ & $\begin{array}{c}28 \\
(20.0) \\
\end{array}$ & $\begin{array}{c}40 \\
(28.6) \\
\end{array}$ & $\begin{array}{c}2.6 \\
(0.49) \\
\end{array}$ \\
\hline $\begin{array}{l}\text { The demand at work makes me } \\
\text { feel exhausted }\end{array}$ & $\begin{array}{c}26 \\
(10.5)\end{array}$ & $\begin{array}{c}122 \\
(49.2)\end{array}$ & $\begin{array}{c}54 \\
(21.8)\end{array}$ & $\begin{array}{c}46 \\
(18.5)\end{array}$ & $\begin{array}{c}2.5 \\
(0.58)\end{array}$ & $\begin{array}{c}18 \\
(12.9)\end{array}$ & $\begin{array}{c}48 \\
(34.3)\end{array}$ & $\begin{array}{c}43 \\
(30.7)\end{array}$ & $\begin{array}{c}31 \\
(22.1)\end{array}$ & $\begin{array}{c}2.4 \\
(0.33)\end{array}$ \\
\hline $\begin{array}{l}\text { I deprive myself from sleep just } \\
\text { to work }\end{array}$ & $\begin{array}{c}54 \\
(21.8) \\
\end{array}$ & $\begin{array}{c}95 \\
(38.3) \\
\end{array}$ & $\begin{array}{c}39 \\
(15.7) \\
\end{array}$ & $\begin{array}{c}60 \\
(24.2) \\
\end{array}$ & $\begin{array}{c}2.6 \\
(0.44) \\
\end{array}$ & $\begin{array}{c}45 \\
(32.1) \\
\end{array}$ & $\begin{array}{c}25 \\
(17.9) \\
\end{array}$ & $\begin{array}{c}26 \\
(18.6) \\
\end{array}$ & $\begin{array}{c}44 \\
(31.4) \\
\end{array}$ & $\begin{array}{c}2.5 \\
(0.45) \\
\end{array}$ \\
\hline $\begin{array}{l}\text { The tasks at work make me feel } \\
\text { frustrated overtime }\end{array}$ & $\begin{array}{c}77 \\
(31.0) \\
\end{array}$ & $\begin{array}{c}128 \\
(51.6)\end{array}$ & $\begin{array}{c}31 \\
(12.5) \\
\end{array}$ & $\begin{array}{c}12 \\
(4.8) \\
\end{array}$ & $\begin{array}{c}3.1 \\
(0.73) \\
\end{array}$ & $\begin{array}{c}59 \\
(42.1) \\
\end{array}$ & $\begin{array}{c}50 \\
(35.7) \\
\end{array}$ & $\begin{array}{c}18 \\
(12.9) \\
\end{array}$ & $\begin{array}{c}13 \\
(9.3) \\
\end{array}$ & $\begin{array}{c}3.1 \\
(0.74) \\
\end{array}$ \\
\hline $\begin{array}{l}\text { My work demands make me } \\
\text { feel emotionally drained }\end{array}$ & $\begin{array}{c}66 \\
(26.6)\end{array}$ & $\begin{array}{c}138 \\
(55.63)\end{array}$ & $\begin{array}{c}24 \\
(9.7)\end{array}$ & $\begin{array}{c}20 \\
(8.1)\end{array}$ & $\begin{array}{c}3.0 \\
(0.75)\end{array}$ & $\begin{array}{c}67 \\
(47.9)\end{array}$ & $\begin{array}{c}38 \\
(27.1)\end{array}$ & $\begin{array}{c}19 \\
(13.6)\end{array}$ & $\begin{array}{c}16 \\
(11.4)\end{array}$ & $\begin{array}{c}3.1 \\
(0.81)\end{array}$ \\
\hline $\begin{array}{l}\text { I feel pressured in taking } \\
\text { decisions when the doctor is not } \\
\text { present at emergency situations }\end{array}$ & $\begin{array}{c}133 \\
(53.6)\end{array}$ & $\begin{array}{c}85 \\
(34.3)\end{array}$ & $\begin{array}{c}20 \\
(8.1)\end{array}$ & $\begin{array}{c}10 \\
(4.0)\end{array}$ & $\begin{array}{c}3.4 \\
(0.97)\end{array}$ & $\begin{array}{c}70 \\
(50.0)\end{array}$ & $\begin{array}{c}58 \\
(41.4)\end{array}$ & $\begin{array}{c}7 \\
(5.0)\end{array}$ & $\begin{array}{c}5 \\
(3.6)\end{array}$ & $\begin{array}{c}3.4 \\
(095)\end{array}$ \\
\hline $\begin{array}{l}\text { I found it stressful to work with } \\
\text { some colleagues }\end{array}$ & $\begin{array}{c}76 \\
(30.6) \\
\end{array}$ & $\begin{array}{c}145 \\
(58.5) \\
\end{array}$ & $\begin{array}{c}19 \\
(7.7)\end{array}$ & $\begin{array}{c}8 \\
(3.2) \\
\end{array}$ & $\begin{array}{c}3.2 \\
(0.84) \\
\end{array}$ & $\begin{array}{c}74 \\
(52.9) \\
\end{array}$ & $\begin{array}{c}52 \\
(37.1) \\
\end{array}$ & $\begin{array}{c}11 \\
(7.9) \\
\end{array}$ & $\begin{array}{c}3 \\
(2.1) \\
\end{array}$ & $\begin{array}{c}3.4 \\
(0.97) \\
\end{array}$ \\
\hline $\begin{array}{l}\text { I hardly make out time for } \\
\text { myself due to work demands }\end{array}$ & $\begin{array}{c}74 \\
(29.8)\end{array}$ & $\begin{array}{c}98 \\
(39.5)\end{array}$ & $\begin{array}{c}47 \\
(19.0)\end{array}$ & $\begin{array}{c}29 \\
(11.7)\end{array}$ & $\begin{array}{c}2.9 \\
(0.55)\end{array}$ & $\begin{array}{c}32 \\
(22.9)\end{array}$ & $\begin{array}{c}61 \\
(43.6)\end{array}$ & $\begin{array}{c}25 \\
(17.9)\end{array}$ & $\begin{array}{c}22 \\
(15.7)\end{array}$ & $\begin{array}{c}2.7 \\
(0.52)\end{array}$ \\
\hline $\begin{array}{l}\text { I work overtime even when I do } \\
\text { not want }\end{array}$ & $\begin{array}{c}95 \\
(38.3) \\
\end{array}$ & $\begin{array}{c}88 \\
(35.5) \\
\end{array}$ & $\begin{array}{c}42 \\
(16.1) \\
\end{array}$ & $\begin{array}{c}23 \\
(9.3) \\
\end{array}$ & $\begin{array}{c}3.0 \\
(0.66) \\
\end{array}$ & $\begin{array}{c}57 \\
(40.7) \\
\end{array}$ & $\begin{array}{c}38 \\
(27.1) \\
\end{array}$ & $\begin{array}{c}22 \\
(15.7) \\
\end{array}$ & $\begin{array}{c}23 \\
(16.4)\end{array}$ & $\begin{array}{c}2.9 \\
(0.66) \\
\end{array}$ \\
\hline $\begin{array}{l}\text { Attending to patients needs } \\
\text { keep me restless }\end{array}$ & $\begin{array}{c}67 \\
(27.0)\end{array}$ & $\begin{array}{c}149 \\
(60.1)\end{array}$ & $\begin{array}{c}19 \\
(7.7)\end{array}$ & $\begin{array}{c}13 \\
(5.2)\end{array}$ & $\begin{array}{c}3.1 \\
(0.83)\end{array}$ & $\begin{array}{c}70 \\
(50.0)\end{array}$ & $\begin{array}{c}45 \\
(32.1)\end{array}$ & $\begin{array}{c}13 \\
(9.3)\end{array}$ & $\begin{array}{c}12 \\
(8.6)\end{array}$ & $\begin{array}{c}3.2 \\
(0.89)\end{array}$ \\
\hline $\begin{array}{l}\text { I worry over mistakes that may } \\
\text { put a patient's life at risk }\end{array}$ & $\begin{array}{c}62 \\
(25.0)\end{array}$ & $\begin{array}{c}64 \\
(25.8)\end{array}$ & $\begin{array}{c}43 \\
(17.3)\end{array}$ & $\begin{array}{c}79 \\
(31.9)\end{array}$ & $\begin{array}{c}2.4 \\
(0.33)\end{array}$ & $\begin{array}{c}26 \\
(18.6)\end{array}$ & $\begin{array}{c}29 \\
(20.7)\end{array}$ & $\begin{array}{c}32 \\
(22.9)\end{array}$ & $\begin{array}{c}53 \\
(37.9)\end{array}$ & $\begin{array}{c}2.2 \\
(0.16)\end{array}$ \\
\hline $\begin{array}{l}\text { I find it stressful to engage in a } \\
\text { non-nursing task while on duty }\end{array}$ & $\begin{array}{c}71 \\
(28.6) \\
\end{array}$ & $\begin{array}{c}75 \\
(30.2) \\
\end{array}$ & $\begin{array}{c}40 \\
(16.1) \\
\end{array}$ & $\begin{array}{c}62 \\
(25.0) \\
\end{array}$ & $\begin{array}{c}2.6 \\
(0.44) \\
\end{array}$ & $\begin{array}{c}26 \\
(18.6) \\
\end{array}$ & $\begin{array}{c}42 \\
(30.0)\end{array}$ & $\begin{array}{c}26 \\
(18.6)\end{array}$ & $\begin{array}{c}46 \\
(32.9)\end{array}$ & $\begin{array}{c}2.3 \\
(0.28)\end{array}$ \\
\hline I feel I work more than I earn & $\begin{array}{c}23 \\
(9.3)\end{array}$ & $\begin{array}{c}44 \\
(17.7)\end{array}$ & $\begin{array}{c}47 \\
(19.0)\end{array}$ & $\begin{array}{c}134 \\
(54.0)\end{array}$ & $\begin{array}{c}1.8 \\
(0.09)\end{array}$ & $\begin{array}{c}11 \\
(7.9)\end{array}$ & $\begin{array}{c}19 \\
(13.6)\end{array}$ & $\begin{array}{c}25 \\
(17.9)\end{array}$ & $\begin{array}{c}85 \\
(60.7)\end{array}$ & $\begin{array}{c}1.7 \\
(0.13)\end{array}$ \\
\hline $\begin{array}{l}\text { Some patients tend to be } \\
\text { abusive in the course of } \\
\text { treatment }\end{array}$ & $\begin{array}{c}13 \\
(5.2)\end{array}$ & $\begin{array}{c}99 \\
(39.9)\end{array}$ & $\begin{array}{c}69 \\
(27.8)\end{array}$ & $\begin{array}{c}67 \\
(27.0)\end{array}$ & $\begin{array}{c}2.9 \\
(0.68)\end{array}$ & $\begin{array}{c}8 \\
(5.7)\end{array}$ & $\begin{array}{c}45 \\
(32.1)\end{array}$ & $\begin{array}{c}32 \\
(22.9)\end{array}$ & $\begin{array}{c}55 \\
(39.3)\end{array}$ & $\begin{array}{c}2.0 \\
(0.32)\end{array}$ \\
\hline $\begin{array}{l}\text { watching a patient suffer/die is } \\
\text { emotionally disturbing }\end{array}$ & $\begin{array}{c}17 \\
(6.9)\end{array}$ & $\begin{array}{c}28 \\
(11.3)\end{array}$ & $\begin{array}{c}60 \\
(24.2)\end{array}$ & $\begin{array}{c}143 \\
(57.7)\end{array}$ & $\begin{array}{c}2.6 \\
(0.44)\end{array}$ & $\begin{array}{c}12 \\
(8.6)\end{array}$ & $\begin{array}{c}15 \\
(10.7)\end{array}$ & $\begin{array}{c}23 \\
(16.4)\end{array}$ & $\begin{array}{c}90 \\
(64.3)\end{array}$ & $\begin{array}{c}1.6 \\
(0.16)\end{array}$ \\
\hline $\begin{array}{l}\text { The tasks I handle make me } \\
\text { feel fatigue }\end{array}$ & $\begin{array}{c}63 \\
(25.4)\end{array}$ & $\begin{array}{c}106 \\
(42.7)\end{array}$ & $\begin{array}{c}57 \\
(23.0)\end{array}$ & $\begin{array}{c}22 \\
(8.9)\end{array}$ & $\begin{array}{c}2.5 \\
(0.58)\end{array}$ & $\begin{array}{c}65 \\
(46.4)\end{array}$ & $\begin{array}{c}27 \\
(19.3)\end{array}$ & $\begin{array}{c}28 \\
(20.0)\end{array}$ & $\begin{array}{c}20 \\
(14.3)\end{array}$ & $\begin{array}{c}3.0 \\
(0.76)\end{array}$ \\
\hline My job is stressful & $\begin{array}{c}68 \\
(27.4) \\
\end{array}$ & $\begin{array}{c}95 \\
(38.3) \\
\end{array}$ & $\begin{array}{c}43 \\
(17.3) \\
\end{array}$ & $\begin{array}{c}42 \\
(16.9)\end{array}$ & $\begin{array}{c}2.6 \\
(0.44) \\
\end{array}$ & $\begin{array}{c}54 \\
(38.6) \\
\end{array}$ & $\begin{array}{c}26 \\
(18.6)\end{array}$ & $\begin{array}{c}23 \\
(16.4)\end{array}$ & $\begin{array}{c}37 \\
(26.4) \\
\end{array}$ & $\begin{array}{c}2.7 \\
(0.59)\end{array}$ \\
\hline
\end{tabular}

$\mathrm{MT}=$ Most of the times, OT $=$ Often times, $\mathrm{ST}=$ Sometimes, $\mathrm{R}=$ Rarely, $\mathrm{pt}=$ Point awarded, S.D = Standard Deviation $($ Wilks's Lambda $=$ $0.965, \mathrm{~F}=13.85$, canonical correlation $=0.188, \mathrm{df}=1, \mathrm{p}<0.0001)$.

Table 1 showed the number and percentage frequency of hypertensive and non-hypertensive nurses that were interviewed in this study. The table showed that generally most nurses $63.9 \%$ were not hypertensive and that among the 
hypertensive nurses, majority $90.7 \%$ were indicative of stage one hypertension.

Table 2 showed responses on job stress from nurses in Imo state and their hypertension status. Similar response was obtained among the hypertensive and the non-hypertensive nurses in some of the items. Closer proportion in both groups (22.63\% of the non-hypertensive and $22.1 \%$ hypertensive) stated that their job demand makes them feel tensed most of the times. A significant proportion (34.3\%) of the hypertensive nurses stated that they feel stressful working on night compared with $19.0 \%$ who are non-hypertensive. But the corresponding mean score (2.6) remained the same for both groups. Up to $21.8 \%$ of the non-hypertensive nurses compared with $32.1 \%$ of the hypertensive nurses reported that most of the times they deprive themselves from sleeping just to perform work task. In a similar variation, $31 \%$ nonhypertensive responded that most of the times, the tasks at work make them feel frustrated overtime compared to $42.1 \%$ in the hypertensive. The nurses who responded that "my work demands make me feel emotionally drained" were respectively $26.6 \%$ on non-hypertensive and $47.9 \%$ on hypertensive. The mean score showed variations for two groups with higher score for the non-hypertensive among those that find it stressful to engage in a non-nursing task while on duty (non-hypertensive $=2.6$, hypertensive $=2.3$ ). The mean score among those who responded that some patients tend to be abusive in the course of treatment were "non-hypertensive 2.9, hypertensive 2.0"; and among those who stated that watching a patient suffer/die is emotionally disturbing were "non-hypertensive 2.6, hypertensive 1.6." The score was rather higher in the hypertensive (mean score= 3.0) than the non-hypertensive (mean score $=2.5$ ) among those who responded that the task they handle make them feel fatigued. Significant correlation was found between hypertension and job stress (Wilks's Lambda $=0.965, \mathrm{~F}=13.85, \mathrm{p}<0.0001)$.

\section{DISCUSSION}

Traditionally, the focus of occupational health and safety initiatives has been on chemical, biological and physical exposures, whilst the psychosocial risks at work are still largely neglected and their causes and consequences still insufficiently understood as they pertain to the developing countries. Unlike physical or chemical hazards, work stress has no obvious tangible hazardous agent. This study has revealed the stress that nurses undergo in performance of their tasks. Gamage and De Alwis ${ }^{[20]}$ reported in their study that a considerable number of administrators are badly affected by job stress, and job stress was significantly related to hypertension. Work-related stress follows a pattern of reactions that occurs when workers are presented with work demands not matched to their knowledge, skills or abilities and which challenge their ability to cope. The 'job strain' model proposed by Lewington ${ }^{[21]}$ states that the combination of high job demands and low job decision latitude (high job strain or work stress) will lead to negative physical health outcomes such as hypertension and cardiovascular disease. According to a World Health Organization publication [7], hypertension and other cardiovascular diseases are amongst the main chronic diseases in the developed and developing countries which can very well be attributed to job stress among other factors. It consumes an important proportion of their public health budget. It is estimated to affect about $20 \%$ of the adult population in most countries of the world, and accounts for $20 \%-50 \%$ of all deaths. ${ }^{[22]}$

Nurses are tasked with the responsibility of taking care of their patients and this keeps them away from their families especially for long hours. Those who work night shift have to spend the night in the hospital away from home. Many nurses interviewed in this study complained that it is very stressful working the night shift. Some studies ${ }^{[21-23]}$ have reported an increase in stress level among health 
workers who work at night. This also comes with lack of sleep as they have to stay awake to attend to their patients especially those who need constant attention in the late hours of the night. This can drain the nurses emotionally as some of them reported in this study. Ong et al. ${ }^{[24]}$ reported in their study that nurses are high risk of emotional distress due to their work challenges. Also the pressure of knowing that any mistake on their part could lead to the fatality of a patient can wear on them. In many hospitals in Nigeria especially in the rural areas, doctors are not available and the nurses are the ones who have to make decisions about the life of their patients. With their limited training in managing diseases, they have no choice but to do what they can for their patients in order to save their lives especially in emergency situations. Addo et al. ${ }^{[25]}$ found that a good number of hospitals in the rural areas of Africa only have visiting doctors and in emergency situations, nurses are the one who attend to the patients. This puts them under a lot of pressure and increases their stress level. All of these points can lead to an increase in the blood pressure of the nurse.

\section{CONCLUSION}

In conclusion, nurses in this study complained that their job made them feel tensed, it was stressful working the night shift, and they deprive themselves of sleep in order to do their job. This was more among nurses with hypertension and a correlation was established. It was recommended that stress intervention programmes be introduced to encourage nurses to manage stress in the workplace. Health insurance must be provided for nurses, whether in the private or public health institutions.

\section{Acknowledgement: None}

\section{Conflict of Interest: None}

Source of Funding: None

\section{Ethical Approval: Approved}

\section{REFERENCES}

1. Bosu KW, Reilly TS, Aheto KMJ, Zucchelli E. Hypertension in older adults in Africa: a systematic review and meta-analysis. Public Library of Science ONE. 2015; 14(4):1-25.

2. World Health Organization. Global Health Observatory Data. 2010. Available at: https://www.who.int/gho/ncd/risk_factorss/b lood_pressure_prevalence_text/en/ [Retrieved 10th May 2011]

3. Tabbrizi JS, Sadeghi BH, Farahbakhsh M, Nikniaz LZ. Prevalence and associated factors of prehypertension and hypertension in Iranian population: the lifestyle promotion project (LPP). Public Library of Science One. 2016; 11(10): 3-15.

4. Thomas G. Diastolic hypertension. The Journal of Clinical Hypertension, 2003; 5(6): 411-413.

5. Akpa MR, Emem-Chioma PC, Odia OJ. Current epidemiology of hypertension in Port Harcourt Metropolis, Rivers State, Nigeria. Port Harcourt Medical Journal. 2013; 2(3): 218-223.

6. Yemi RR, Taiwo A, Oye G. Awareness of hypertension and its impact on blood pressure control among elderly Nigerians: report from the Ibadan study of aging. Pan African Medical Journal, 2017; 27(5): 182190.

7. World Health Organization. Global health risks: mortality and burden of disease attributable to selected major risks. Global status report on non-communicable diseases. 2016.

8. National Centre for Health Statistics. National Health and Nutrition Examination Survey (NHANES) Examination Manuel's 2013-2014, USA. 2016, 2-6.

9. Senyahy L. Hypertension as a chronic disease: what can be done at the regional level? National institute of health. Canadian Journal of Cardiology. 2018; 24(6): 483490.

10. Jiang W, Zhang L, Wang F, Liu L. Prevalence, awareness, treatment and control of hypertension in China: results from a national survey. PubMed. 2014; 27(11): 1355-61.

11. Ekpenyong CE, Udokang NE, Akpan EE, Samson TK. Double burden, nonCommunicable Disease and risk factors 
evaluation in sub-Saharan Africa: the Nigerian Experience. European Journal of Sustainable Development. 2012; 1(2), 49270.

12. Knutsson H. Effect of work shift on hypertension: cross sectional study. Journal Annual Occupational Environmental Medicine. 2013; 29: 11-16.

13. Larkin KT. Stress and hypertension: examining the relation between psychological stress and high blood pressure. Yale University Press. 2015.

14. Landsbergis PA, Schnall PL, Warren K, Pickering TG, Schwartz JE. Association between ambulatory blood pressure and alternative formulations of job strain. Scandinavian Journal of Work Environmental Health. 2014; 20: 349-363.

15. Reddy KS. India wakes up to the threat of cardiovascular diseases. Journal of American College of Cardiology. 2017; 50: 1370-132.

16. Lou L, Shiau C. Counselling Psychology Quarterly. Occupational Stress in Clinical Nurses. 1997; 10(1): 39-51.

17. Rosengren L, Hawken J, Onupuu L. The effect of job strain on night time blood pressure dipping among men and women with high blood pressure. Scandinavian Journal of Work and Environmental Health. 2004; 39(1): 112-119.

18. Radi S, Lang T, Lauwers V. Job constrains and arterial hypertension: different effect in men and women: the HPAF II case control study. Occupational and Environmental Medicine. 2005; 62, 711-717.

19. Fiaiho C, Cavichio G, Povoa A, Pimenta O. Effect of work strain on blood pressure: a prospective study of male and female white- collar workers. American Journal of Public Health. 2006; 96(8): 1436-1443.

20. Gamage AU, De Alwis SR. Perceived job stress and presence of hypertension among administrative officers in Sri Lanka. Asia Pacific Journal of Public Health. 2016; 28(1): 41-42.

21. Lewington S. The burden of hypertension and associated risk for cardiovascular mortality in China. Journal of American Medical Association International Medicine. 2012; 176(4): 532-533.

22. Houtma I, Jettinghoff $\mathrm{K}$, Cedillo L. Protecting workers: raising awareness of stress at work in developing countries; advice to employers and workers. World Health Organization publication. 2017.

23. Kaczorowski J, Chambers LW, Karwalajtys T, Dolovich L, Farrell B, McDonough B. Cardiovascular health awareness program (CHAP): a community cluster-randomized trial among elderly Canadians. Prev Med. 2008; 46(6): 537-544.

24. Ong KL, Cheung BM, Man YB, Lau CP, Lam KS. Prevalence, awareness, treatment, and control of hypertension among United States adults 1999-2004. Hypertension. 2007; 49(1): 69-75.

25. Addo J, Smeeth L, Leon DA. Hypertension in sub-Saharan Africa: A systematic review. Hypertension, 2007; 50(6): 1012-1018.

How to cite this article: Chinedu-Eleonu, P.O., Obasi, C.C., Nsonwu, M.C. et.al. Association of job stress and hypertension among nurses in Imo State, Nigeria. International Journal of Science \& Healthcare Research. 2021; 6(3): 309-314. DOI: https://doi.org/10.52403/ijshr.20210753 